\title{
THE ANNUAL MEETING OF THE SOCIETY
}

The forty-seventh Annual Meeting of the American Mathematical Society was held at Louisiana State University, Baton Rouge, Louisiana, from Monday, December 30, 1940 to Wednesday, January 1, 1941 , in conjunction with meetings of the Mathematical Association of America and the National Council of Teachers of Mathematics.

There were four general and six sectional sessions of the Society at which three addresses and ninety research papers (forty in person) were given. All sessions were held in Nicholson Hall of Louisiana State University.

Arrangements for the meetings were made by a committee of which Professor S. T. Sanders was chairman and Professors W. V. Parker and N. E. Rutt were the local members. Through the generosity of Louisiana State University, rooms were available in three of the University dormitories.

The attendance was about 500, including the following one hundred ninety-three members of the Society:

Leonidas Alaoglu, A. A. Aucoin, W. L. Ayres, R. W. Babcock, I. A. Barnett, R. E. Basye, P. O. Bell, E. E. Betz, S. F. Bibb, D. H. Blackwell, H. E. Bray, R. W. Brink, J. C. Brixey, F. L. Brooks, R. H. Bruck, H. E. Buchanan, R. S. Burington, J. E. Burnam, L. E. Bush, W. E. Byrne, W. D. Cairns, C. C. Camp, M. E. Carlen, W. B. Carver, J. E. Case, C. R. Cassity, J. H. Chanler, E. W. Chittenden, M. D. Clement, L. M. Coffin, L. W. Cohen, Nancy Cole, J. B. Coleman, E. G. H. Comfort, H. H. Conwell, L. P. Copeland, W. A. Cordrey, N. A. Court, W. H. H. Cowles, M. J. Cox, G. F. Cramer, D. R. Curtiss, J. H. Curtiss, R. D. Daugherty, W. M. Davis, C. C. Dearman, L. J. Deck, Douglas Derry, L. L. Dines, J. L. Dorroh, W. L. Duren, John Dyer-Bennet, E. D. Eaves, Samuel Eilenberg, E. R. Elliott, H. J. Ettlinger, G. C. Evans, W. K. Feller, B. F. Finkel, H. T. Fleddermann, T. C. Fry, H. K. Fulmer, R. E. Gaskell, B. E. Gatewood, F. C. Gentry, J. S. Gold, Cornelius Gouwens, C. H. Graves, J. W. Green, R. E. Greenwood, D. W. Hall, O. H. Hamilton, E. H. Hanson, O. G. Harrold, W. L. Hart, W. W. Hart, M. C. Hartley, J. O. Hassler, K. E. Hazard, L. B. Hedge, G. A. Hedlund, R. A. Hefner, M. L. Hill, I. M. Hostetter, M. G. Humphreys, Witold Hurewicz, W. A. Hurwitz, Dunham Jackson, R. L. Jackson, Nathan Jacobson, Fritz John, F. B. Jones, M. L. Kales, H. S. Kaltenborn, D. E. Kearney, J. L. Kelley, A. J. Kempner, E. C. Kennedy, E. S. Kennedy, G. S. Ketchum, P. W. Ketchum, J. R. Kline, E. C. Klipple, J. C. Knipp, C. C. Krieger, M. E. Ladue, J. P. LaSalle, C. G. Latimer, Walter Leighton, R. G. Lubben, Dorothy McCoy, Dora McFarland, Roy MacKay, Saunders MacLane, A. E. Many, William Marshall, L. E. Mehlenbacher, A. N. Milgram, D. D. Miller, W. L. Miser, Virginia Modesitt, Deane Montgomery, Richard Morris, T. A. Mossman, E. J. Moulton, S. B. Myers, J. P. Nash, Albert Neuhaus, C. V. Newsom, E. N. Nilson, N. M. Oboukhoff, Rufus Oldenburger, E. G. Olds, E. R. Ott, F. W. Owens, H. B. Owens, W. V. Parker, E. W. Pehrson, I. E. Perlin, O. J. Peterson, B. J. Pettis, G. B. Price, A. S. Rayl, Maxwell Reade, D. P. Richardson, R. G. D. Richardson, F. D. Rigby, R. F. Rinehart, C. V. Robinson, J. B. Rosser, N. E. Rutt, S. T. Sanders, Samuel Saslaw, G. E. 
Schweigert, J. A. G. Shirk, M. M. Slotnick, C. D. Smith, C. E. Smith, E. R. Smith, H. L. Smith, H. W. Smith, W. F. Smith, W. S. Snyder, R. H. Sorgenfrey, C. E. Springer, D. W. Starr, N. E. Steenrod, R. C. Stephens, R. W. Stokes, E. B. Stouffer, W. T. Stratton, Otto Szász, J. D. Tamarkin, J. M. Thomas, A. W. Tucker, L. I. Wade, T. L. Wade, C. C. Wagner, R. W. Wagner, R. K. Wakerling, R. J. Walker, J. A. Ward, L. E. Ward, W. G. Warnock, Marjorie Watson, M. J. Weiss, F. P. Welch, M. E. Wescott, R. L. Wilder, F. B. Wiley, R. M. Winger, F. L. Wren, Leo Zippin.

The meetings of the Society opened Monday afternoon with two sections, Analysis, and Algebra and Topology, with Professors G. B. Price and L. W. Cohen presiding. This was followed by a general session at which Dr. Leo Zippin gave an address entitled Topology of rigid motions. Professor J. R. Kline presided.

On Monday evening there were two sections, Algebra with Professor Nathan Jacobson presiding, and Geometry with Professor S. B. Myers presiding.

On Tuesday morning there was a general session for short papers at which President G. C. Evans presided. Following this Professor Saunders MacLane gave an address entitled Extensions of groups at a general session at which Professor J. D. Tamarkin presided.

The annual business meeting and election of officers was held on Wednesday morning. President G. C. Evans presided. This was followed by a general session at which Professor G. C. Evans gave his retiring address as President of the Society. The title of this address was Surfaces of minimum capacity. Vice President T. C. Fry presided at this address.

The sessions of the Society closed on Wednesday afternoon with two sections, Analysis and Topology, with Professors H. J. Ettlinger and N. E. Steenrod presiding.

Sessions of the Mathematical Association of America were held on Wednesday morning, jointly with the National Council of Teachers of Mathematics, and on Thursday morning. The National Council of Teachers of Mathematics held sessions on Monday morning, afternoon and evening, Tuesday morning, and Wednesday morning.

On Monday afternoon a tea was given in the Faculty Club by President and Mrs. P. M. Hebert of Louisiana State University.

On Tuesday afternoon there was an excursion by automobile to visit some fine antebellum homes and gardens near St. Francisville.

A joint dinner for members of all three mathematical organizations and their guests was held on Wednesday evening in Foster Hall. The attendance was two hundred ninety-one. Professor F. A. Rickey was toastmaster. He introduced Dr. P. M. Hebert, President of Louisiana State University, who welcomed the mathematicians on behalf of the 
University. Other speakers, representing the three organizations, were Professors H. E. Buchanan and C. V. Newsom, and Miss Mary A. Potter. Between the speeches Miss Marguerite Muncelle entertained with music on the harp and Miss Weslyn Stephens with vocal solos. President G. C. Evans presented to Dean R. G. D. Richardson, on behalf of the Council of the Society, a beautiful hand-illuminated copy of the resolution of appreciation adopted by the Council on the occasion of his retirement as Secretary of the Society, together with a silver coffee set and for Mrs. Richardson a hand bag. President Evans also read telegrams of congratulations to Dean Richardson from the Department of Mathematics of the University of Wisconsin and from Professor Marston Morse, the newly elected President of the Society. At the close of the dinner Professor R. M. Winger presented resolutions, which were adopted unanimously, thanking Louisiana State University and the members of its Department of Mathematics for their excellent arrangements and gracious hospitality.

At the meeting of the Board of Trustees at 6:00 P.M., December 30, 1940 , in the library of the Faculty Club of Louisiana State University, there was no quorum present. An adjourned meeting, therefore, was held on January 6, 1941, at 5:00 P.M. in the Men's Faculty Club of Columbia University, New York City.

The Council met on Tuesday, December 31, at 7:30 P.M. in the Faculty Club at Louisiana State University; an adjourned meeting was held at 4:15 P.M. on Wednesday at the same place.

The Secretary announced the election of the following eighteen persons to membership in the Society:

Dr. Alfredo Baños, Jr., Institute of Physics, National University of Mexico;

Mr. Virgil P. Barta, Portland, Ore.;

Professor Clair J. Blackall, College of St. Thomas, St. Paul, Minn.;

Mr. Aaron Herschfeld, U. S. Social Security Board, Washington, D. C.;

Mr. Gerhard Paul Hochschild, Princeton University;

Dr. Houston T. Karnes, Louisiana State University;

Mr. Jacob Louis Miller, Brooklyn, N. Y.;

Mr. Vernon V. Quilliam, Adohr Milk Farms, Los Angeles, Calif.;

Mr. John S. Ripandelli, Forest Hills, Long Island, N. Y.;

Dr. Raphaël Salem, Montreal, Quebec, Canada;

Professor Conway C. Sams, Mars Hill College, Mars Hill, N. C.;

Dr. Kenneth Charles Schraut, University of Dayton;

Professor Sire, University of Lyon, Lyon, France;

Professor Frederick Franklin Stephan, Cornell University;

Dr. Alfred Tarski, Harvard University;

Sister Mary Felice Vaudreuil, Mount Mary College, Milwaukee, Wis.;

Brother Bernard Alfred Welch, Manhattan College, New York, N. Y.;

Professor Antoni Zygmund, Mount Holyoke College. 
It was reported that the following had been elected as nominees on the Institutional Memberships of the institutions indicated:

Brooklyn College: Mr. Bernard Greenspan.

Brown University: Dr. George Polya.

University of California: Miss Julia Hall Bowman, Messrs. George Bernard Dantzig, Stanley Phillips Frankel, Robert J. Levit, James Vernon Lewis, Martin Lewis Nelson, and Samuel A. Schaaf.

University of California at Los Angeles: Messrs. Clarence Maurice Ablow and Robert Simple Arthur.

University of Cincinnati: Mr. Harry Sears Kieval.

College of the City of New York: Mr. Joshua Barlaz.

Columbia University: Messrs. Lawrence Annenberg and Richard M. Cohen, Miss Martha Isabel Fields, Messrs. Abraham Hillman and Chung-Tsi Hsu.

Cornell University: Messrs. Norman Gustav Gunderson and Theodore Hailperin.

Harvard University: Professor Percy Williams Bridgman, Messrs. Paul Ernest Guenther and Irving Kaplansky, Professor Edwin Crawford Kemble, Messrs. George Whitelaw Mackey and Frank Moore Stewart.

University of Illinois: Messrs. Thad Paul Alton, William Franklin Atchison, Ernest Evred Blanche, Dickran Hagop Erkiletian, Arthur Edward Hallerberg, and Richard W. Hamming, Miss Mary Jeannette Hurst, Mr. Paul Ben Johnson, Miss Lois Kiefer, Messrs. Ernest Reuben Kolsrud, Brooks Javins Lockhart, Charles Willard Mathews, Gottfried Emanuel Noether, and James Ferris Price. Institute for Advanced Study: Professor Shizuo Kakutani.

Iowa State College: Mr. Charles J. Thorne.

State University of Iowa: Mr. Franklin E. Satterthwaite.

The Johns Hopkins University: Messrs. Clagett Bowie, Carl Henry Bradshaw, and Earl Alexander Coddington, Miss Mary Theresa Curran, Dr. Frederick Weiss Light, Jr., Mr. Bernard Sherman.

University of Kentucky: Mrs. Aughtum S. Howard.

Massachusetts Institute of Technology: Messrs. Kenneth James Arnold, Elliott Lyndon Buell, and Henry Earl Singleton.

University of Michigan: Messrs. Ivor Schilansky and Bernard Vinograde.

Michigan State College of Agriculture and Applied Science: Mr. Joseph Willard Sheedy.

Northwestern University: Messrs. Arthur Saastad and Zenon Szatrowski.

University of Pennsylvania: Messrs. Nathan Jacob Fine and Joseph Lehner.

Pennsylvania State College: Dr. Allen Byron Cunningham.

The College of St. Thomas: Professor Rolf Landshoff.

Smith College: Miss Alexandra Illmer.

University of Toronto: Messrs. Nathan Saul Mendelsohn and Albert Wallace Walker. University of Virginia: Messrs. Truman Arthur Botts and Walter Helbig Gottschalk. University of Washington: Mr. Fumio Yagi.

University of Wisconsin: Messrs. John Oswald Danielson, Robert Stewart Gardner, Allison Potter Loomer, Nels David Nelson, Thomas Edmond Oberbeck, Lowell J. Paige, and Robert L. Wilson.

Yale University: Messrs. Andrew Mattei Gleason, Gerald Robinson MacLane, and Sidney Trachtenberg.

The following appointments by President G. C. Evans or the Coun- 
cil were reported: as Committee on Arrangements for the Spring Meeting in Washington, D. C., May 2-3, 1941, Professors F. E. Johnston (chairman), E. J. Finan, T. R. Hollcroft, Florence M. Mears, J. H. Taylor, E. W. Titt, and F. M. Weida; as Committee on Arrangements for the Annual Meeting of 1941 at Lehigh University, Dean Tomlinson Fort (chairman), Professors T. R. Hollcroft, Everett Pitcher, G. E. Raynor, and W. M. Smith; as representative of the Society at the inauguration of Samuel Nowell Stevens as sixth president of Grinnell College (Grinnell, Iowa) on October 25, Professor W. J. Rusk; as representative of the Society at the inauguration of Raymon M. Kistler as president of Beaver College (Glenside, Pa.) on November 8, Professor Anna Pell Wheeler; as representative of the Society at the inauguration of Carl Stephens Ell as president of Northeastern University (Boston, Mass.) on November 19, Professor E. V. Huntington; as representative of the Society at the inauguration of James Franklin Findlay as president of Drury College (Springfield, Mo.) on November 29, Dr. F. T. H'Doubler; as an additional member of the Committee on Publicity, Professor R. J. Walker; as auditors of the Society's books for 1940, Professors R. G. Archibald and A. E. Meder, Jr.; as tellers for the election at the 1940 Annual Meeting, Dr. E. R. Lorch and Professor W. V. Parker; as new members of the Committees to Select Hour Speakers: for Annual and Summer Meetings, Professor M. H. Ingraham (committee now consists of Professors J. R. Kline, chairman, Einar Hille, C. R. Adams, and M. H. Ingraham); for Western Sectional Meetings, Professor W. J. Trjitzinsky (committee now consists of Professors W. L. Ayres, chairman, E. W. Chittenden, and W. J. Trjitzinsky); for Far Western Sectional Meetings, Professor T. Y. Thomas (committee now consists of Professors T. M. Putnam, chairman, Gabor Szegö, and T. Y. Thomas); as Colloquium speaker for 1943, Professor E. J. McShane; as representatives on the Editorial Board of the Duke Mathematical Journal for 1941-1943, Professors F. J. Murray and Morgan Ward.

The Secretary reported that the ordinary membership in the Society is now 2,336, including 213 nominees of institutional members and 78 life members. There are also 87 institutional members. The total attendance of members at all meetings in 1940 was 1,441 ; the number of papers read was 498 ; the number of invited addresses was 13; the number of members attending at least one meeting was 921.

At the annual election which closed on January 1, and at which 384 votes were cast, the following officers were elected:

President, Professor Marston Morse.

Vice President, Professor T. Y. Thomas. 
Secretary, Professor J. R. Kline.

Associate Secretary, Professor T. R. Hollcroft.

Treasurer, Professor B. P. Gill.

Member of the Editorial Committee of the Bulletin, Professor L. M. Graves.

Member of the Editorial Committee of the Transactions, Professor Einar Hille.

Member of the Editorial Committee of the American Journal of Mathematics, Professor Hermann Weyl.

Member of the Editorial Committee of the Colloquium Publications, Professor G. T. Whyburn.

Members of the Council at Large, Professors L. R. Ford, G. B. Price, Tibor Radó, A. W. Tucker, and Morgan Ward.

Members of the Board of Trustees, Professors W. R. Longley, Marston Morse, and G. W. Mullins, Dean R. G. D. Richardson, and Dr. Warren Weaver.

At the business meeting following the annual election of officers, the following resolution, adopted by the Council at the Summer Meeting at Hanover, was read, and by a unanimous rising vote, the Society added its approval of this Council action:

\section{To Roland George Dwight Richardson}

The American Mathematical Society has been exceedingly fortunate in having had three devoted and able secretaries. Thomas Scott Fiske (1888-1895), Frank Nelson Cole (1895-1920), and Roland George Dwight Richardson (1921-1940). The achievements of the first two have been noted elsewhere in the archives of the Society. It is desire of the Council of the Society at its present meeting to record its grateful appreciation of the services of Richardson who will retire from office in December 1940. He was elected to the secretaryship in 1921, in the period of danger and uncertainty following the world war of 1914-1918. It was a time in the history of the Society when the never-ending tension between too slowly increasing financial resources and the costs of continuously increasing facilities for encouragement of mathematical research was most acute. By his persistent continuation of the campaigns for membership, his watchful interest in the resources of the Society, his sympathetic understanding of our research needs, and his constant and unifyingly friendly influence in the management of our affairs, Richardson has taken a most prominent part in insuring the financial safety and developing the scientific influence of the Society. He has devoted himself, 
often to the limit of his strength, to our interests. In contrast to these selfsacrificing services our comments here must inevitably seem inadequate and incomplete. Richardson's real memorial lies, however, in the affection and admiration for him which are widespread among the present members of the Society, and universal among those who have known him personally and worked with him. For future generations of members the Society itself and its scientific resources will constitute an ineffaceable reminder of his effective interest.

In view of these invaluable services the Council hereby directs that a copy of these statements shall be spread upon the records of the Society, and that a copy shall also be sent, as an expression of our high regard, to our retiring Secretary.

The reports of the Treasurer and Auditors showed a balance of $\$ 6,966.39$ in the general account and exclusive of the balances in the Colloquium, Sinking Fund, and other special funds. The Society's investments including Endowment Fund, Mathematical Reviews Fund, Colloquium Fund, and other special funds had a market value on November 30, 1940 of approximately $\$ 170,000$. The interest income for the year was $\$ 6,909.41$; dues from Institutional Memberships amounted to $\$ 6,705.00$; dues from Contributing Memberships $\$ 1,114.92$; dues from Ordinary Memberships $\$ 14,380.96$. The Colloquium Fund showed a balance on hand of $\$ 9,718.95$. The total received from the sale of the Society's publications was $\$ 18,148.02$. The regular account of Mathematical Reviews showed income from subscriptions of $\$ 7,849.48$, from investments of $\$ 2,469.99$, and disbursements of approximately $\$ 11,800.00$. The Board of Trustees adopted a budget for 1941 showing authorized expenditures and estimated receipts of the Society as $\$ 50,700$ and $\$ 41,900$ respectively. A sum of $\$ 1,000$ from the income of the Marion Reilly Fund was appropriated for Mathematical Reviews and a similar sum for a volume of the Colloquium Publications. A copy of the Treasurer's report will, on request, be sent to any member of the Society.

On recommendation of the Committee on Places of Meetings (Professor E. W. Chittenden, chairman), the Annual Meeting of 1941 was set at Lehigh University, Bethlehem, Pa., December 30-January 1, and the Annual Meeting of 1942 for New York City in connection with the sessions of the American Association for the Advancement of Science. Times and places of meetings during 1941 were also set as follows: fall midwestern meeting at Kansas State College, Manhattan, on November 21-22, and fall far western meeting at Pasadena on November 22. 
The Librarian reported that the Library of the Society now contains about 9721 volumes.

The American Journal of Mathematics, which is published jointly by the Johns Hopkins University and the Society, and to which the Society contributes an annual subvention of $\$ 2,500$, printed 912 pages during 1940.

The Committee on War Preparedness presented a report. A copy may be obtained on request to Secretary Kline. The present membership of the Committee is as follows:

Chairman, Professor Marston Morse.

Subcommittee on Research, Professors Dunham Jackson (chairman), E. J. McShane, M. H. Stone, J. H. Van Vleck, Norbert Wiener, S. S. Wilks.

Subcommittee on Preparation for Research, Professors M. H. Stone (chairman), B. O. Koopman, R. E. Langer, Hans Lewy, F. D. Murnaghan, H. P. Robertson.

Subcommitee on Education for Service, Professors W. L. Hart (chairman), R. S. Burington, J. L. Coolidge, H. B. Curry, E. C. Goldsworthy, F. L. Griffin, M. H. Ingraham, E. J. Moulton.

Consultants, Aeronautics-Professor Harry Bateman, Chief; Ballistics-Professor John von Neumann, Chief, Professor W. T. Reid; Computation-Professor Norbert Wiener, Chief; CryptanalysisProfessor H. T. Engstrom, Chief, A. A. Albert, W. A. Hurwitz, Solomon Kullback, Oystein Ore; Industry-Dr. T. C. Fry, Chief; Probability and Statistics-Professor S. S. Wilks, Chief.

The Secretary reported that during his term of office the membership of the Society had more than tripled (733-2,336).

President Marston Morse appointed as the Committee on Nomination of Officers and Members of the Council for 1942, Professors G. A. Bliss (chairman), G. C. Evans, Philip Franklin, T. H. Hildebrandt, and P. A. Smith.

The Committee on Scientific Aids to Learning with a view to aiding the use of microfilm as well as to supporting Mathematical Reviews has appropriated $\$ 10,000$ for purchase of Student Microfilm Readers (see this Bulletin, p. 1). It was reported that over 6,000 notices regarding the Student Microfilm Readers had been sent to individuals and libraries and that applications for more than 350 of these machines had been received by Mathematical Reviews during the last ten days of 1940 .

Revision of the By-Laws to take care of the Society's arrangements for Mathematical Reviews, to reduce the number of ex-officio voting members of the Council, and to make other minor changes, was rec- 
ommended for favorable action; the revised By-Laws are to be presented for adoption at the February meeting of the Society.

A committee consisting of Professors E. W. Chittenden (chairman), T. H. Hildebrandt, H. P. Robertson, J. D. Tamarkin, and J. L. Walsh was appointed to consider and to make recommendations to the Council concerning the possible introduction of a new series of mathematical books.

The Committee on Addresses in Applied Mathematics reported through its chairman, Professor Richard Courant, recommendations for a vigorous program in connection with various meetings of mathematicians.

Titles and cross references to the abstracts of papers read at the regular sessions follow below. The papers were read as follows: Papers numbered 1-6 in the section for Analysis on Monday afternoon; papers 7-11 in the section for Algebra and Topology on Monday afternoon; papers $12-17$ in the section for Algebra on Monday evening; papers 18-23 in the section for Geometry on Monday evening; papers 24-29 in the general session on Tuesday morning; papers 30-34 in the section for Analysis on Wednesday afternoon; papers 35-40 in the section for Topology on Wednesday afternoon; and papers 41-90, whose abstract numbers are followed by the letter $t$, were read by title. Mr. R. L. Swain and Miss Harlan C. Miller were introduced by Professor R. L. Moore, Mr. Nelson Robinson by Professor W. V. Parker, Professor Szolem Mandelbrojt by Professor H. E. Bray, and Dr. Russell Cowan by Professor W. G. Warnock. Paper 2 was presented by Mr. E. N. Nelson, and paper 18 by Dr. C. V. Robinson.

1. J. W. Green: A special type of conformal map. (Abstract 47-1-25.)

2. J. L. Walsh and E. N. Nilson: Approximation to an analytic function by functions analytic and bounded in a region. (Abstract 47-152.)

3. W. S. Snyder: On independence of the path for line integrals of continuous functions. (Abstract 47-1-45.)

4. J. P. LaSalle: Pseudo-normed linear sets over valued rings. II. (Abstract 47-1-95.)

5. I. E. Perlin: Indefinitely differentiable functions of several real variables. (Abstract 47-1-40.)

6. L. B. Hedge: Transformations of multiple Fourier series. Preliminary report. (Abstract 47-1-28.)

7. N. E. Rutt: Rectangular arrays of combinations. (Abstract 47-18.)

8. R. W. Wagner: The differentials of analytic matrix functions. (Abstract 47-1-11.) 
9. R. H. Sorgenfrey: Concerning triodic continua. (Abstract 47-1105.)

10. R. L. Swain: Distance axioms in Moore spaces. (Abstract 47-1106.)

11. J. L. Kelley: A theorem on transformations. (Abstract 47-3-178.)

12. T. L. Wade: Tensor algebra and Young's symmetry operators. (Abstract 47-1-10.)

13. C. C. Camp: A root cubing method of solving equations. (Abstract 47-1-2.)

14. L. I. Wade: Certain quantities transcendental over the field $G F\left(p^{n}, x\right)$. (Abstract 47-1-87.)

15. Douglas Derry: On the boundary case of Minkowski's linear form theorem. Preliminary report. (Abstract 47-1-81.)

16. Rufus Oldenburger: The minimal number problem. (Abstract 47-1-6.)

17. R. H. Bruck: The structure of the rational representations of $a$ wide class of linear groups. (Abstract 47-1-1.)

18. L. M. Blumenthal and C. V. Robinson: Helly theorems on the sphere. (Abstract 47-1-67.)

19. N. A. Court: On the skew cubic. (Abstract 47-1-73.)

20. E. R. Ott: $A$ locus determined by an algebraic correspondence. (Abstract 46-11-497.)

21. P. O. Bell: On differential geometry intrinsically connected with a surface element of projective arc length. (Abstract 47-1-65.)

22. C. R. Cassity: The double points of a pencil of cubics invariant under the quadratic transformation. (Abstract 47-1-68.)

23. Nelson Robinson: On the contact of a quartic surface with a general analytic surface. (Abstract 47-3-164.)

24. L. L. Dines: On the mapping of quadratic forms. (Abstract 47-119.)

25. J. B. Rosser: Explicit bounds for some functions of prime numbers. (Abstract 47-1-85.)

26. S. B. Myers: Complete Riemannian manifolds of positive mean curvature. (Abstract 47-1-74.)

27. J. M. Thomas: Orderly differential systems. (Abstract 47-1-49.)

28. A. N. Milgram: Extensions of decompositions. (Abstract 47-197.)

29. Szolem Mandelbrojt: On a Dirichlet series. (Abstract 47-3-137.)

30. B. E. Gatewood: Thermal stresses in regions bounded by epitrochords. (Abstract 47-1-59.)

31. Russell Cowan: $A$ method of solving a linear difference equation with polynomial coefficients of degree $m$. (Abstract 47-1-16.) 
32. J. H. Curtiss: Trigonometric interpolation by means of the complex Lagrange polynomial. (Abstract 47-1-18.)

33. Fritz John: On the character of solutions of hyperbolic equations. Preliminary report. (Abstract 47-1-32.)

34. Otto Szász: On the partial sums of harmonic developments and related power series. (Abstract 47-1-47.)

35. Harlan C. Miller: Concerning certain types of end points of compact continua. (Abstract 47-1-98.)

36. G. E. Schweigert: Border transformations. (Abstract 47-1-104.)

37. O. G. Harrold: On a class of continuous maps. (Abstract 47-192.)

38. R. L. Wilder: Characterizations of those euclidean domains whose boundaries are $l c^{k}$. (Abstract 47-1-112.)

39. Samuel Eilenberg: Imbedding of spaces into euclidean spaces. Preliminary report. (Abstract 47-1-90.)

40. F. B. Jones: Topologically flat spaces. (Abstract 47-1-93.)

41. S. E. Warschawski: On conformal mapping of infinite strips. (Abstract 47-3-146-t.)

42. R. P. Boas and D. V. Widder: Completely convex functions. Preliminary report. (Abstract 47-1-15-t.)

43. W. D. Duthie: Segments in ordered sets. (Abstract 47-1-3-t.)

44. P. M. Swingle: An abstraction of types of connected sets. (Abstract 47-1-108-t.)

45. L. M. Blumenthal: Betweenness in metric ptolemaic spaces. (Abstract 47-1-66-t.)

46. J. J. Eachus: Classification of solutions and of pairs of solutions of $y^{\prime \prime \prime}+2 p(x) y^{\prime}+p^{\prime}(x) y=0$ by means of boundary conditions. (Abstract 47-1-21-t.)

47. C. N. Moore: On the Cesàro and Abel-Poisson summalility of the differentiated double Fourier series. (Abstract 47-1-38-t.)

48. H. L. Garabedian: Relations between hypergeometric methods of summation. (Abstract 47-1-24-t.)

49. C. W. Vickery: A new proof of a theorem of Chittenden. (Abstract 47-1-111-t.)

50. J. Marcinkiewicz and Antoni Zygmund: On the behavior of trigonometric and power series. (Abstract 47-1-36-t.)

51. Hyman Serbin: Upper bounds for the remainder of certain power series. (Abstract 47-1-44-t.)

52. H. S. Wall: $A$ theorem on real functions bounded in the unit circle. (Abstract 47-1-51-t.)

53. R. E. Greenwood: Hankel and other extensions of Dirichlet series. (Abstract 47-1-26-t.) 
54. Walter Leighton: On the convergence of continued fractions. (Abstract 47-1-35-t.)

55. Warren Ambrose: Representation of ergodic flows. Preliminary report. (Abstract 47-1-14-t.)

56. A. E. Heins: On the solution of partial difference equations. Two interval "boundary conditions." Preliminary report. (Abstract 47-129-t.)

57. N. E. Rutt: Sets with a certain sort of derived set. (Abstract 47-1103-t.)

58. Nathaniel Coburn: A note on conformal geometry. (Abstract 471-69-t.)

59. Nathaniel Coburn: Unitary spaces with corresponding geodesics. (Abstract 47-1-70-t.)

60. H. M. Schwartz: Convex functions and the law of the mean. (Abstract 47-1-42-t.)

61. H. M. Schwartz: Sequences of Stieltjes integrals. (Abstract 471-43-t.)

62. Arthur Sard: The measure of the critical values of differentiable maps of euclidean spaces. (Abstract 47-1-41-t.)

63. M. F. Smiley: Measurability and distributivity in the theory of lattices. (Abstract 47-1-9-t.)

64. Jesse Douglas: Solution of the inverse problem of the calculus of variations. (Abstract 47-1-20-t.)

65. J. H. Curtiss: Degree of polynomial approximation on a lemniscate. (Abstract 47-1-17-t.)

66. N. A. Court: On the harmonic pole. (Abstract 47-1-72-t.)

67. G. D. Nichols: A sufficient condition for Cesàro summability. (Abstract 47-1-39-t.)

68. R. L. Wilder: On the domains complementary to continua having certain avoidability properties. (Abstract 47-1-113-t.)

69. R. L. Wilder: The duality between the S-properties of closed sets and their complements in the euclidean n-sphere. (Abstract 47-1-114-t.)

70. Hermann Weyl: Theory of reduction for arithmetical equivalence. II. (Abstract 47-1-13-t.)

71. C. J. Everett: An extension theory for rings. (Abstract 47-1-4-t.)

72. D. V. Widder: Necessary and sufficient conditions for the representation of a function in Lidstone series. (Abstract 47-1-54-t.)

73. Eric Reissner: A new derivation of the equations for the deformation of elastic shells. (Abstract 47-1-63-t.)

74. Harlan C. Miller: On the existence of a certain type of irreducible continuum. (Abstract 47-1-99-t.) 
75. Harlan C. Miller and R. L. Swain: Properties of two intersecting arcs. (Abstract 47-1-100-t.)

76. R. L. Swain: Linear metric space. (Abstract 47-1-107-t.)

77. Abraham Spitzbart: Approximation in the sense of least pth powers by polynomials with a single auxiliary condition of interpolation. (Abstract 47-1-46-t.)

78. F. B. Hildebrand: The approximate solution of singular integral equations arising in engineering practice. (Abstract 47-1-60-t.)

79. Leonard Carlitz: Finite differences and polynomials in a Galois field. (Abstract 47-1-80-t.)

80. Samuel Eilenberg: Monotone families of manifolds. (Abstract 47-1-91-t.)

81. S. B. Myers: Compact groups whose elements are of finite order. (Abstract 47-1-101-t.)

82. M. R. Hestenes: Extension of the range of a differentiable function. (Abstract 47-1-30-t.)

83. Richard Courant: Critical points and unstable minimal surfaces. (Abstract 47-1-71-t.)

84. W. J. Trjitzinsky: Analytic theory of singular elliptic partial differential equations. (Abstract 47-1-50-t.)

85. Gordon Pall: Simultaneous representation in a quadratic and linear form. (Abstract 47-1-83-t.)

86. N. M. Oboukhoff: On the validity of total differential as the principal part of the increment of a function of two or more variables. (Abstract 47-3-138-t.)

87. Oscar Zariski: Pencils on an algebraic variety and a new proof of a theorem of Bertini. (Abstract 47-3-167-t.)

88. Edward Kasner and J. J. DeCicco: The classification of analytic arcs or elements under the group of arbitrary point transformations. (Abstract 47-3-162-t.)

89. R. P. Agnew: On methods of summability and mass functions determined by hypergeometric coefficients. (Abstract 47-3-125-t.)

90. E. S. Allen and Harvey Diehl: The enumeration of glycols. (Abstract 47-3-147-t.)

\author{
W. L. Ayres, \\ Associate Secretary
}

